\title{
Pitaya (Dragon Fruit) (Hylocereus undatus) Pests and Beneficial Insects'
}

\author{
Daniel Carrillo, Rita Duncan, and Jorge E. Peña ${ }^{2}$
}

Pitaya (pitahaya) or dragon fruit, Hylocereus undatus (Haworth) Britton \& Rose (Cactaceae) is an emerging crop in south Florida. Acreage of this fruit crop in Florida has grown rapidly and shows a good potential for commercialization. This fact sheet contains some of the pests and beneficial insects associated with it.

\section{Key Pests}

\section{Thrips}

Several species of thrips (Thysanoptera: Thripidae) can be found on pitaya plants in south Florida. The species most commonly found are Frankliniella occidentalis Pergande (Figure 1), Scirtothrips dorsalis Hood (Figure 2), Thrips palmi Karny, F. bispinosa (Morgan), F. kelliae (Sakimura), and F. insularis (Franklin) (Figure 3); the first three of these have been found to be common pests. These are slender insects, about $1.5 \mathrm{~mm}$ long with piercing and sucking mouthparts and the adults have delicate, slender wings. Females insert their eggs into the flowers or young fruit. The larvae (Figure 4) feed on these tender tissues and generally pupate in the soil. They have a short life cycle, can have up to 10 generations per year, and prefer dry periods from October to April (Capinera 2015; Childers and Nakahara 2006). Thrips scar the fruit as they feed, cause deformation when ovipositing their eggs, and leave fecal deposits that turn reddish brown to black (Figure 5). The unsightly damage has rendered $20 \%$ to $80 \%$ of the fruit unmarketable during years with high populations. Thrips can live and reproduce on many of the plants grown in south Florida, including avocado, mango, lychee, peppers, and on common weeds (i.e., pigweed, spiny amaranth, balsam apple [Childers and Nakahara 2006]). Because weeds are a habitat, weed management can be an important control measure, and visual inspections of pitaya flowers or sticky cards (blue, white, or yellow) can be used to monitor populations (Capinera 2015). Thrips are known for their ability to develop resistance to insecticides. They do have some natural enemies, such as ladybugs, lacewing larvae (see Generalist Beneficial Fauna section), predatory mites, and the minute pirate bug; some of these are also used as biocontrol agents.

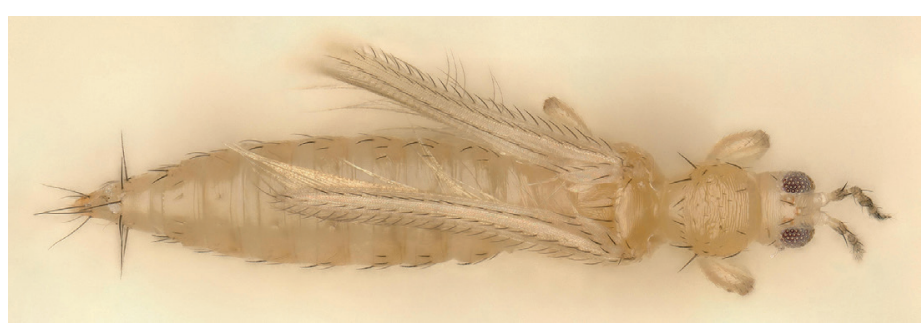

Figure 1. An adult western flower thrips, Frankliniella occidentalis Pergande. Determined by J. Xian, 2016.

Credits: Daniel Carrillo, UF/IFAS

1. This document is ENY-2050, one of a series of the Department of Entomology and Nematology, UF/IFAS Extension. Original publication date September 2020. Visit the EDIS website at https://edis.ifas.ufl.edu for the currently supported version of this publication.

2. Daniel Carrillo, assistant professor, Department of Entomology and Nematology; Rita Duncan, senior biological scientist, fruit crop entomology, Department of Entomology and Nematology; and Jorge E. Peña, professor emeritus, Department of Entomology and Nematology; UF/IFAS Tropical Research and Education Center; UF/IFAS Extension, Gainesville, FL 32611.

The Institute of Food and Agricultural Sciences (IFAS) is an Equal Opportunity Institution authorized to provide research, educational information and other services

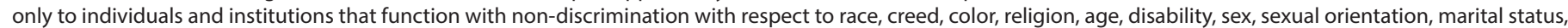

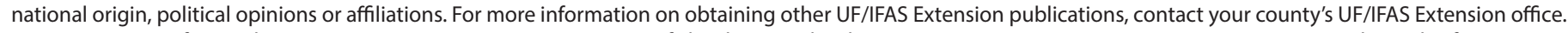
U.S. Department of Agriculture, UF/IFAS Extension Service, University of Florida, IFAS, Florida A \& M University Cooperative Extension Program, and Boards of County Commissioners Cooperating. Nick T. Place, dean for UF/IFAS Extension. 


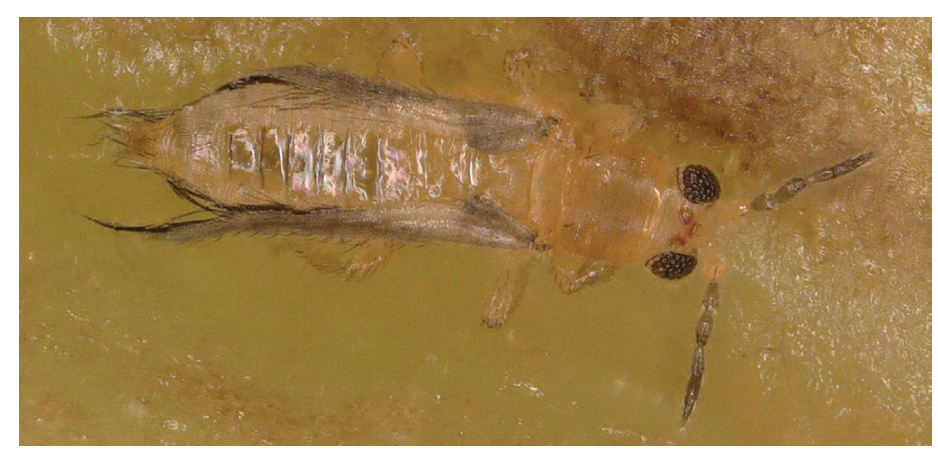

Figure 2. An adult thrips, Scirtothrips dorsalis Hood. Determined by K. Williams, 6 Aug. 2015.

Credits: Rita Duncan, UF/IFAS

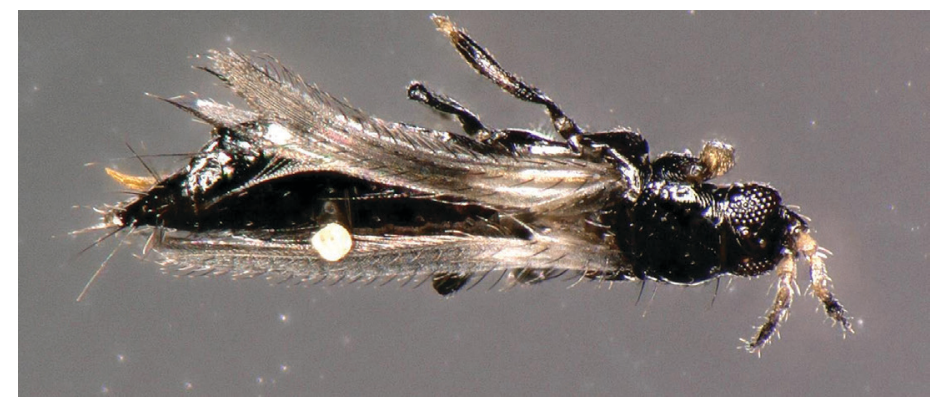

Figure 3. Frankliniella insularis (Franklin), a thrips found in pitaya flowers, with pollen grains attached to it. Determined by F. SotoAdams, 11 Jun 2019.

Credits: Rita Duncan, UF/IFAS

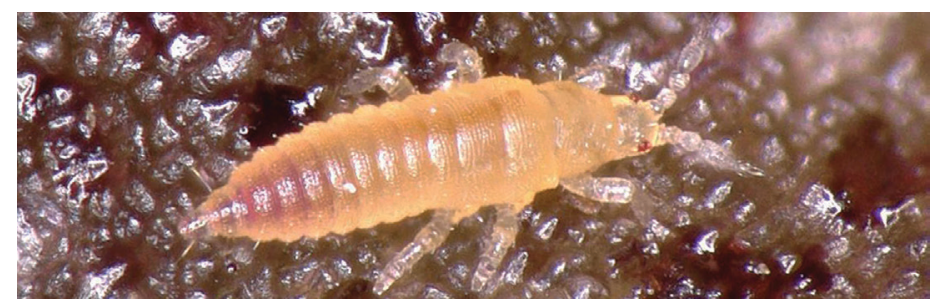

Figure 4. An immature thrips feeding on pitaya sepals and the reddish fecal deposits it has left behind.

Credits: Daniel Carrillo, UF/IFAS

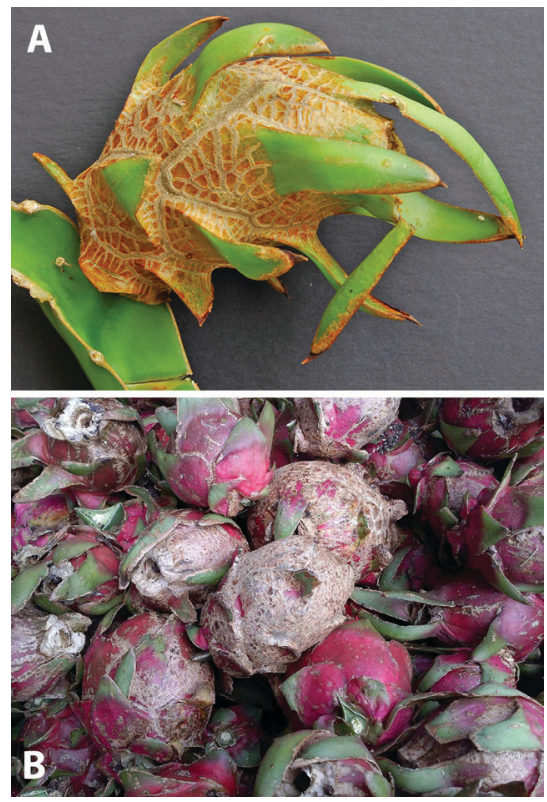

Figure 5. Fruit made unmarketable by scarring from thrips. Credits: Daniel Carrillo, UF/IFAS

\section{Leaf-Footed Bugs}

Two species of leaf-footed bugs, Leptoglossus concolor (Walker) and Leptoglossus phyllopus (Linnaeus), (Hemiptera: Coreidae) have been found damaging pitaya fruits in south Florida (Figures 6 and 7). These are conspicuous insects (20-25 $\mathrm{mm}$ long) that make a buzzing sound during flight. Feeding produces unsightly punctures that result in poor quality fruit (Figure 8) and may allow bacteria and fungi to enter the fruit. They can also damage the stems and arms of pitaya plants; this damage is represented as deep puncture wounds (Figure 9). Eggs are laid in a row along the stems, on fruits, or on weeds around the crop (Figure 10). These are true bugs, the immatures (nymphs) resemble the adults in shape but are flightless, and their large, leaf-shaped hind tibias develop only in the latter instars. Leaf-footed bugs are generally considered minor pests, but occasionally large numbers accumulate and cause economic damage. In south Florida, leaf-footed bugs are present throughout the year; they feed on pitaya, guava, carambola, papaya, passion fruit, citrus, and vegetable crops in the fall and winter (Peña et al. 2002; and personal observation). Weeds are also a source of food and oviposition sites, and therefore cultural control can be an important factor in controlling them (Chi 2012). There are some tachinid flies (Diptera: Tachinidae) that attack adults, and some wasps (Hymenoptera) in the Eupelmidae and Scelionidae families attack the eggs of leaf-footed bugs (Xiao 2009).

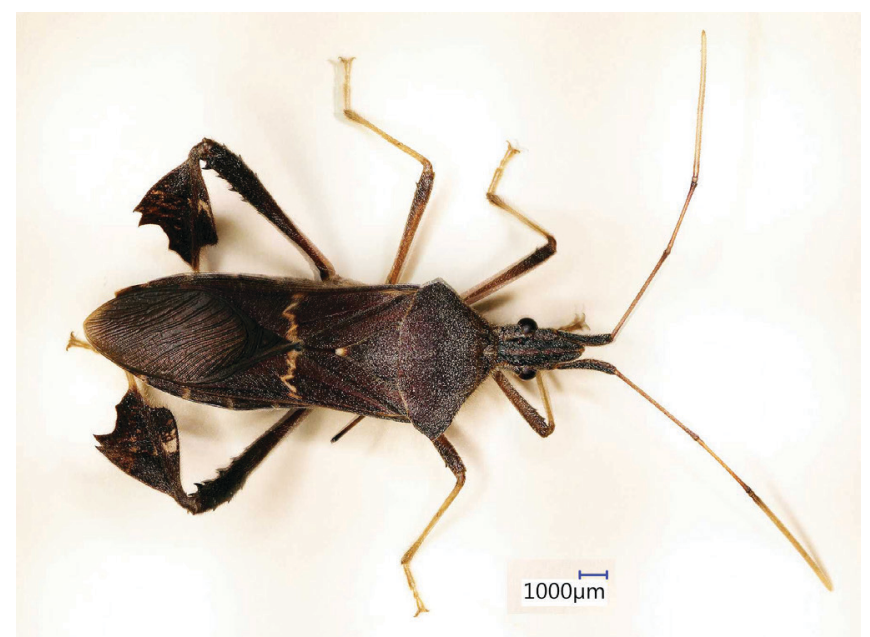

Figure 6. Leptoglossus concolor (Walker), a leaf-footed bug. Determined by S. Halbert, 3 Nov. 2015.

Credits: Rita Duncan, UF/IFAS

\section{Aphids}

Two species of aphids (Hemiptera: Aphididae), Aphis craccivora Koch (Figure 11) and Aphis gossypii Glover (Figure 12), have been found feeding on the flowers and fruits of pitaya plants in south Florida. Adults of both species are blackish brown and about $2 \mathrm{~mm}$ long. Immatures feeding 
on this crop can range from light gray to green. Aphids are viviparous, which means that they give live birth. They have protrusions on their backs called cornicles (Figure 12); some have wings, but most are apterous, or wingless. They are soft-bodied, slow-moving, sucking insects and exude a sugary, sticky substance called honeydew that becomes a breeding ground for sooty mold (Figure 13). The sooty mold is very difficult to clean and diminishes the market value of fruit. Ants also feed on this honeydew and to maintain this food source, they protect aphids from natural enemies and transport them to new sites where these aphids start new colonies (Figure 14). This interaction may contribute to increases in aphid populations. Aphids are active throughout the year in south Florida. There are several species of hymenopteran parasitoids (wasps) that are beneficial to people because they are natural enemies of aphids. These wasps lay their eggs in the aphid, and as the parasitoid grows inside, the aphid mummifies and turns into a hard shell that can be easily recognized (Figure 15). Two of these beneficial parasitoids are Lysiphlebus testaceipes (Cresson) (Hymenoptera: Aphidiidae) and Aphelinus sp. (Hymenoptera: Aphelinidae) (Figure 16). Lady beetles (Figure 35) and lacewings (Figure 36) are also important predators. Aphids are normally not an important pest of pitaya unless their natural enemies are disrupted.

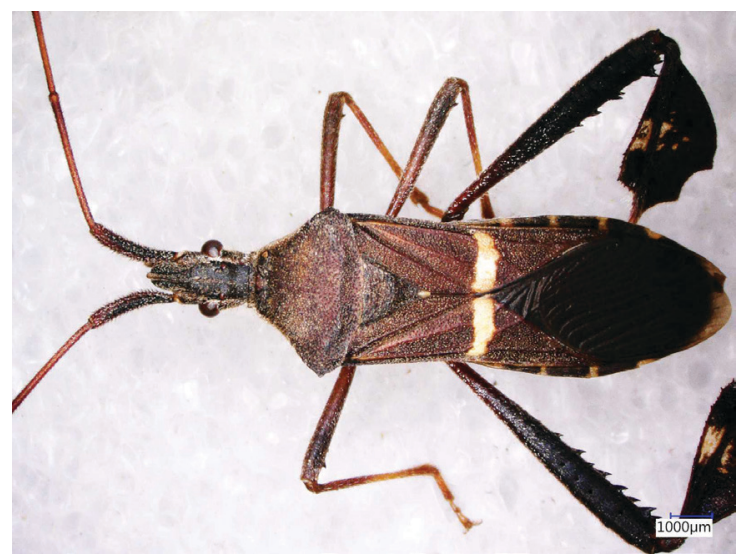

Figure 7. Leptoglossus phyllopus (Linnaeus), a leaf-footed bug. Determined by S. Halbert, 3 Nov. 2015.

Credits: Rita Duncan, UF/IFAS

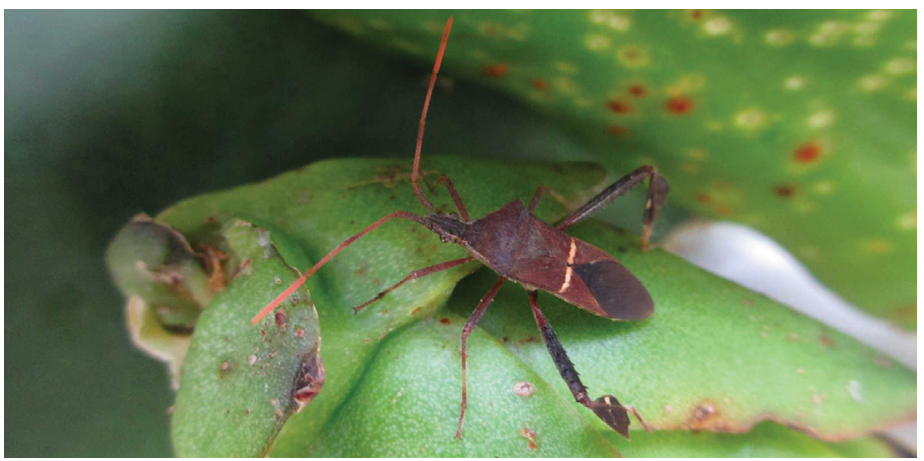

Figure 8. Leaf-footed bug damage to pitaya fruit.

Credits: Daniel Carrillo, UF/IFAS

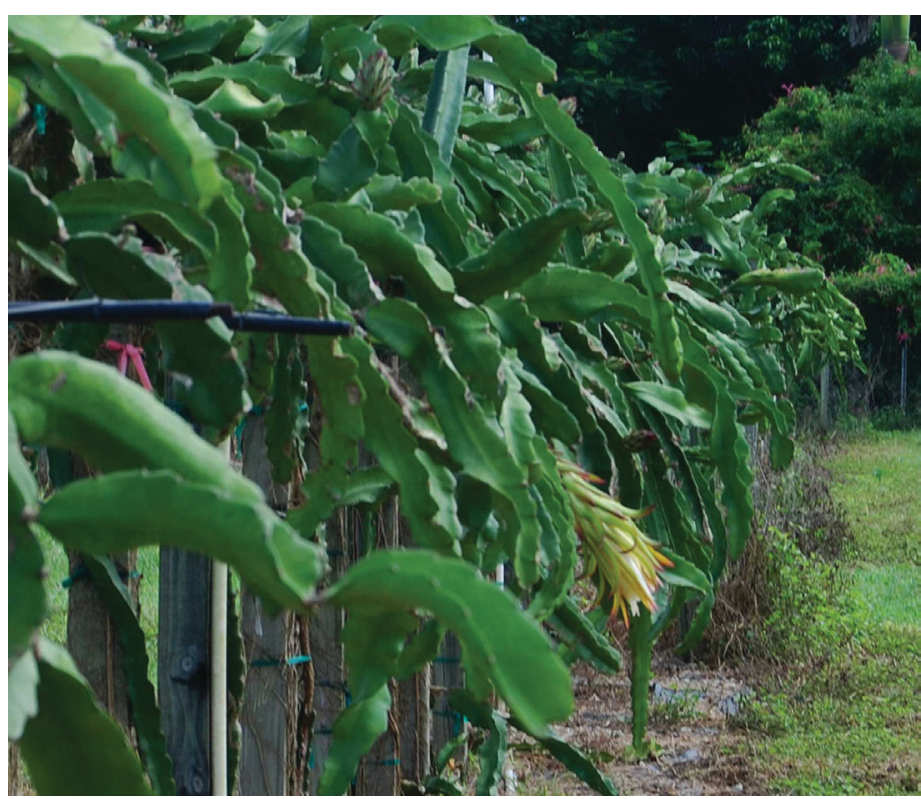

Figure 9. Pitaya cactus plants on a trellis.

Credits: Rita Duncan, UF/IFAS

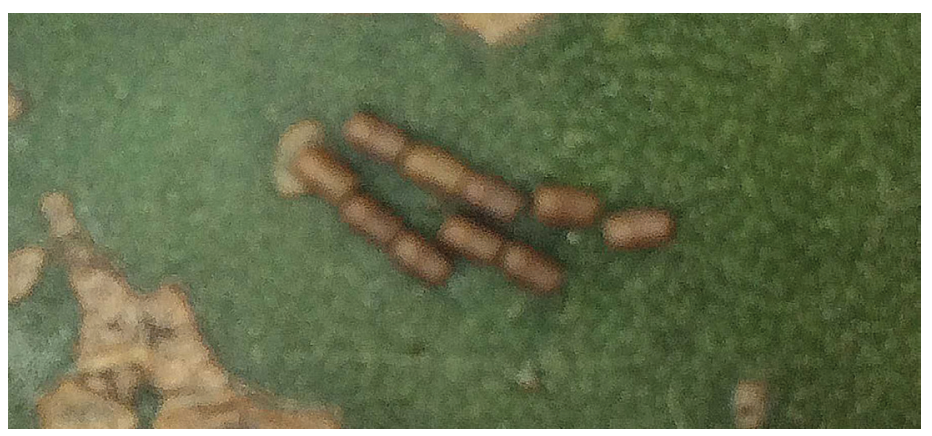

Figure 10. Leaf-footed bug eggs laid in a row or chain along the stem of a pitaya plant.

Credits: Daniel Carrillo, UF/IFAS

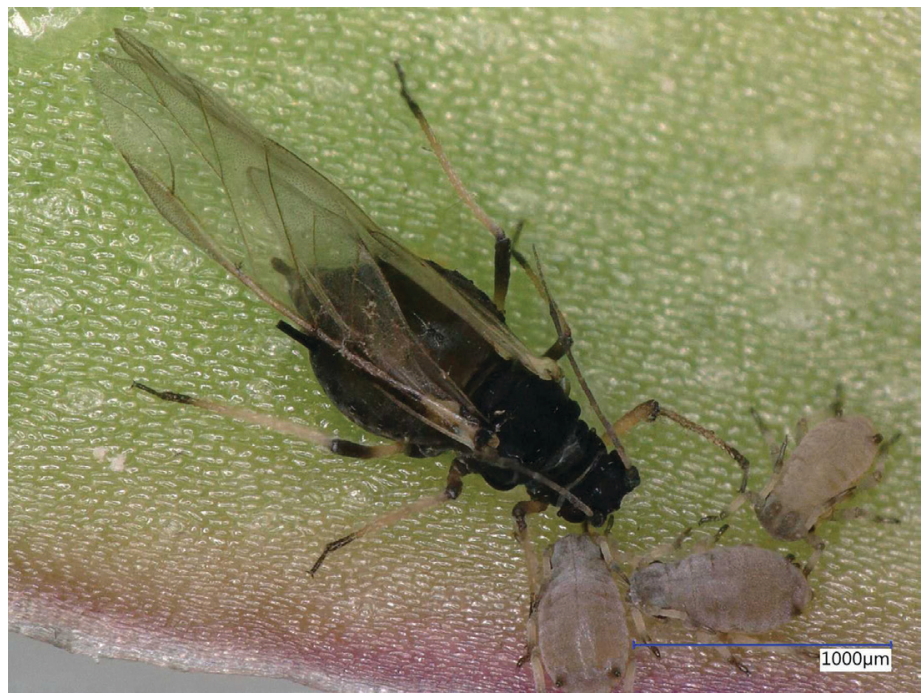

Figure 11. An adult alate aphid with three immatures, Aphis craccivora Koch, on a sepal of a pitaya fruit. Determined by S. Halbert, 3 Nov. 2015.

Credits: Rita Duncan, UF/IFAS 


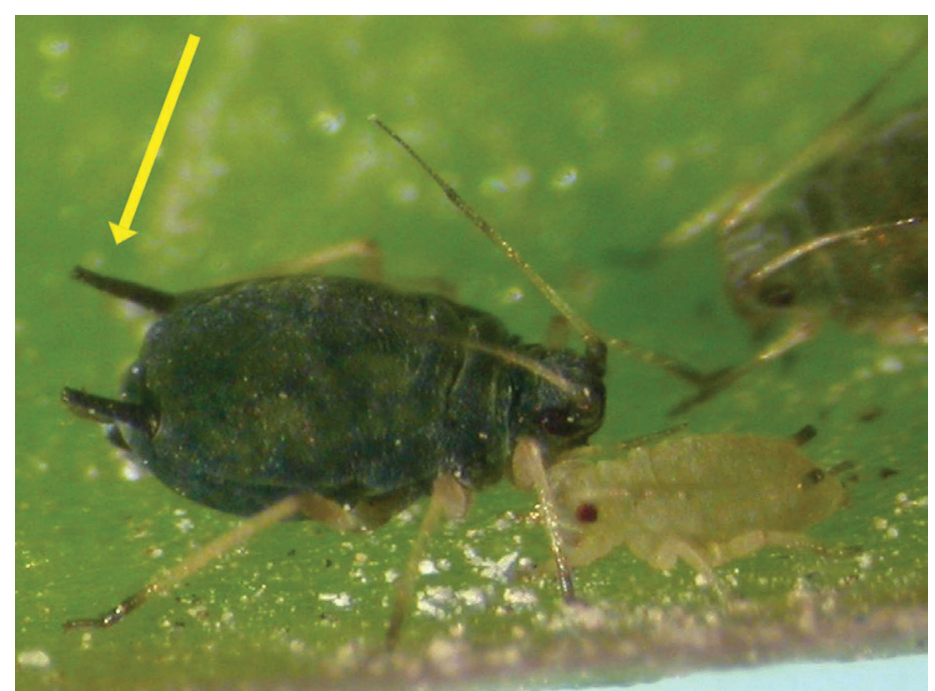

Figure 12. Adult and immature aphids, Aphis gossypii Glover, on a sepal of a pitaya fruit. Yellow arrow pointing to one of the two cornicles. Determined by S. Halbert, 7 Jun 2011.

Credits: Rita Duncan, UF/IFAS
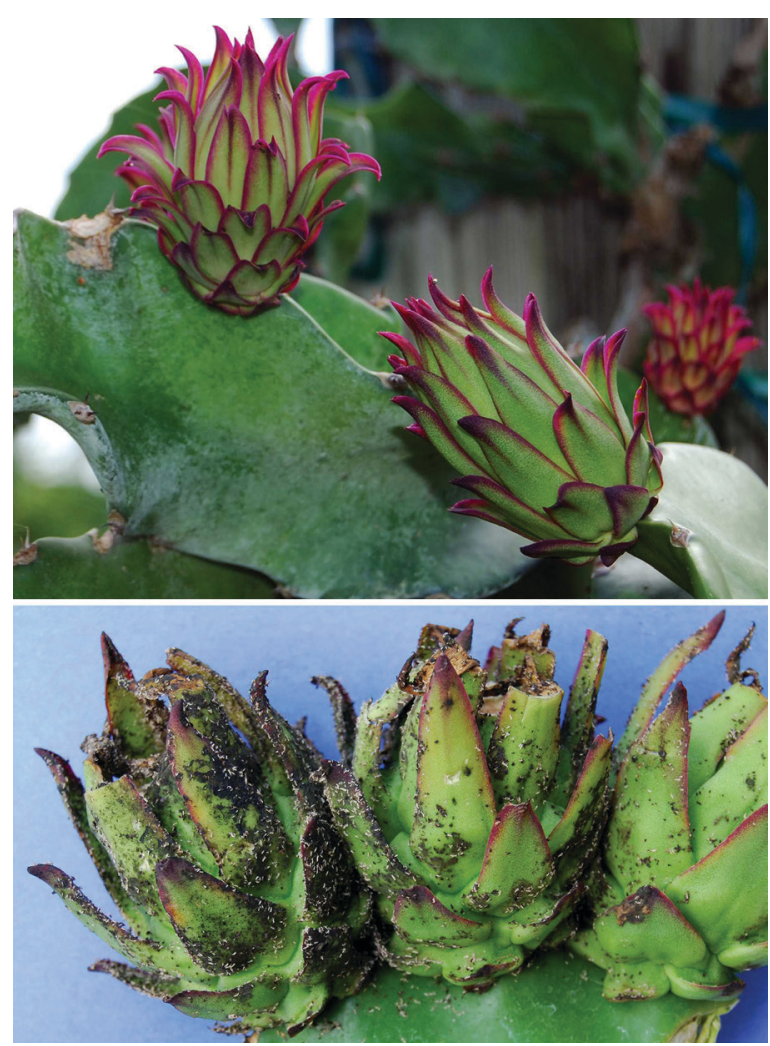

Figure 13. Young pitaya fruits. Top, un-infested; bottom, heavily infested with aphids and covered in black sooty mold.

Credits: Rita Duncan, UF/IFAS

\section{BENEFICIAL PARASITIC WASPS}

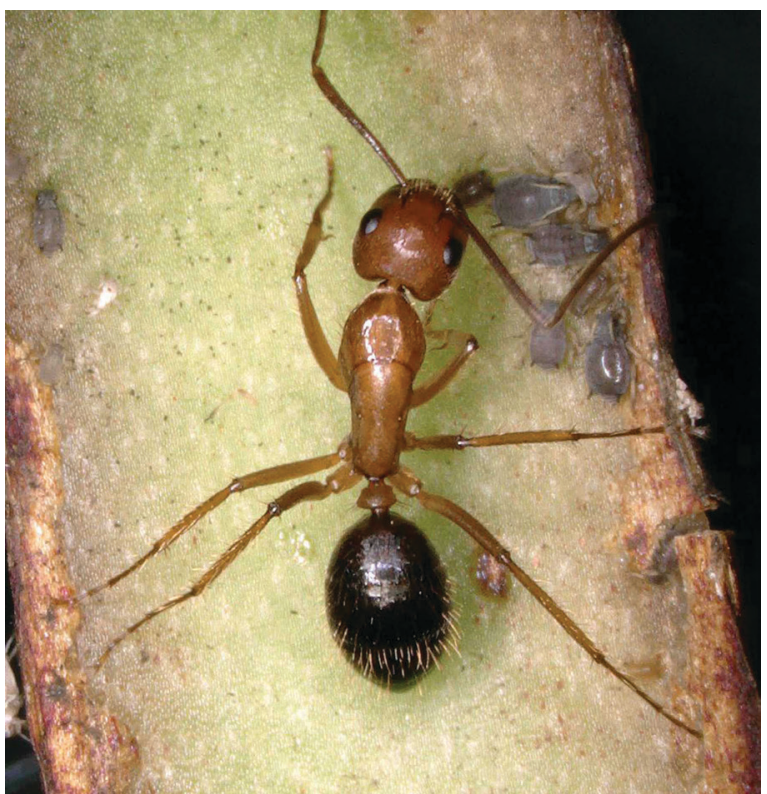

Figure 14. An ant tending an aphid colony.

Credits: Rita Duncan, UF/IFAS
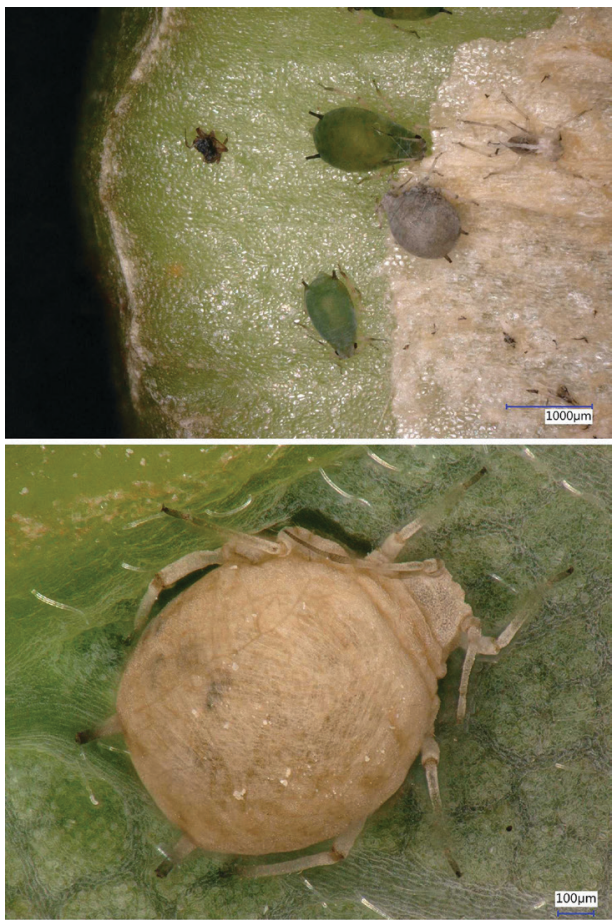

Figure 15. Top, an aphid that has mummified after an attack by a hymenopteran parasitoid next to live aphids; bottom, close-up of mummified aphid.

Credits: Rita Duncan, UF/IFAS 


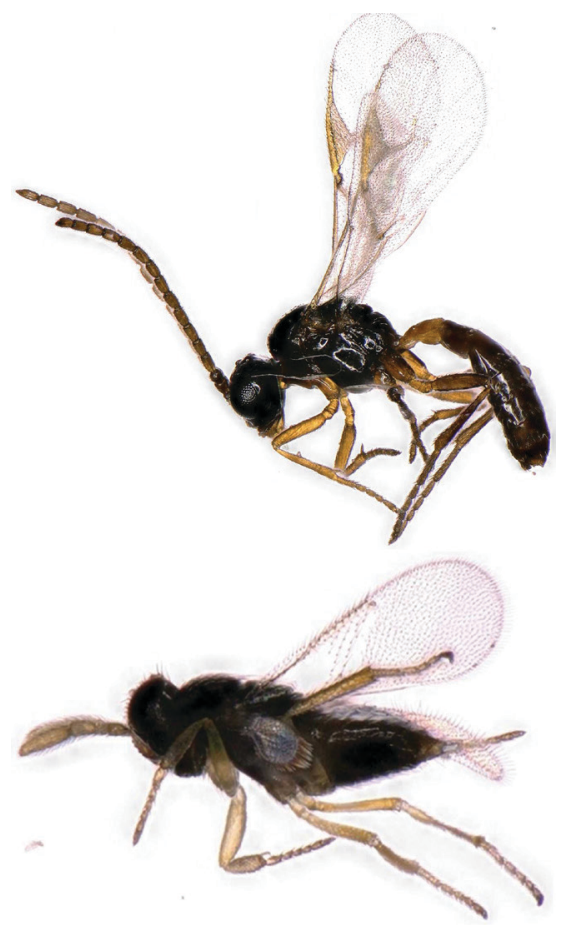

Figure 16. Two species of aphid parasitoids (beneficial parasitic wasps) emerged from the mummified aphids above. Top, Lysiphlebus testaceipes (Cresson); bottom, Aphelinus sp. Determined by E. Talamas, 17 May 2019 and 6 Jun 2019.

Credits: Rita Duncan, UF/IFAS

\section{Mealybugs}

Ferrisia dasylirii (Cockerell) (Hemiptera: Pseudococcidae) is a mealybug that has been identified infesting the flowers and fruits of pitaya. These are small $(4-6 \mathrm{~mm})$ soft-bodied insects with waxy filaments (Figure 17). They insert a stylet into the plant to draw the sap; as they feed and colonize plants, they extrude honeydew, a sugary substance conducive to the growth of sooty mold. The sooty mold inhibits photosynthesis; it is also difficult to remove, making the fruit less marketable. Females reproduce rapidly; they produce pads with eggs. Crawlers (immature stages) hatch and as they begin to crawl can be easily carried by wind currents to infest new plants. Only the males have wings. They are polyphagous and feed on a large number of crops, i.e., papaya, guava, mango, and vegetable crops (Marques et al. 2015). This is a tropical insect that does well in the sub-tropical climate of south Florida and can be found throughout the year. Populations of this mealybug do occasionally increase and become a problem; however, they are normally kept under control with good cultural practices by predators such as ladybugs (Figure 35), lacewing larvae (Figure 36), spiders, and parasitoids. Ants protect mealybug colonies from parasitoids; therefore, controlling ant populations may be necessary. Scouting for mealybugs should include the well-protected areas under the bracts of developing flowers and fruits; infested parts should be removed and destroyed. The mealybug destroyer
(Cryptolaemus montrouzieri [Coleoptera: Coccinellidae]) is a commercial biocontrol agent available for release in greenhouses (McCorquodale and Hodges 2016).

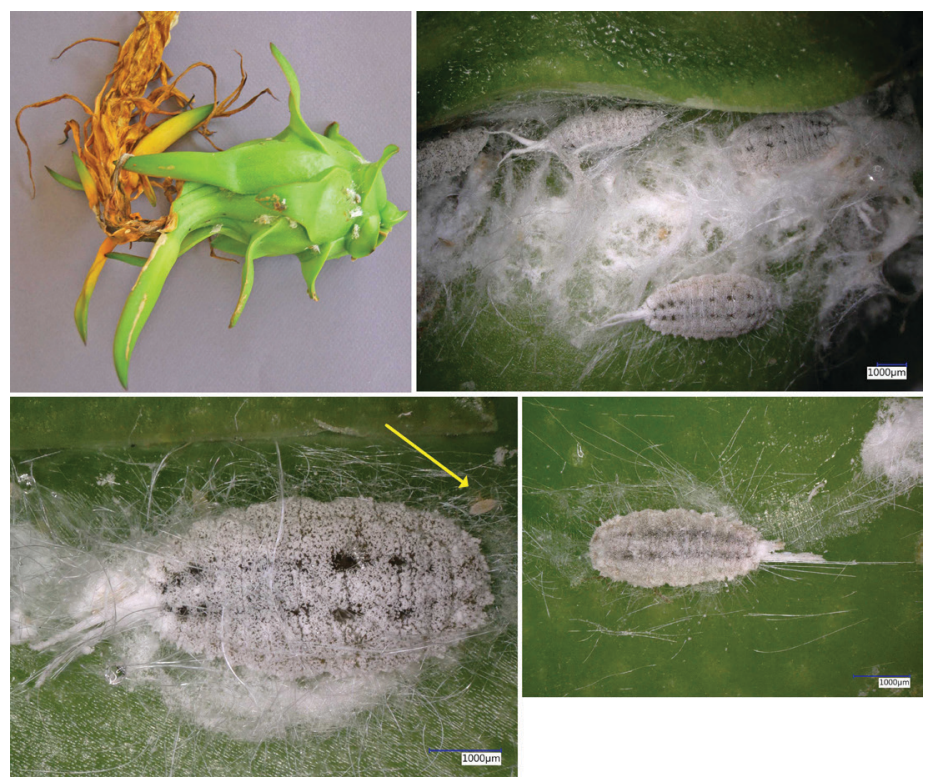

Figure 17. Ferrisia dasylirii (Cockerell), a mealybug infesting flowers and fruits. Top left: young fruit with colonies. Top right: close up of colonies. Bottom left: close up of adult and immatures (yellow arrow). Bottom right: adult. Determined by I. Stocks, 11 Aug 2015.

Credits: Rita Duncan, UF/IFAS

\section{Minor Pests}

\section{Lepidoptera}

The beet armyworm, Spodoptera exigua (Hübner) (Lepidoptera: Noctuidae) (Figure 18), has been found damaging pitaya flowers. Adult moths are nocturnal, about $20 \mathrm{~mm}$ long, and lay their eggs on the petals and sepals. The larvae feeding on pitaya range from a light greenish-white color at first, to darker greens with longitudinal white stripes as they mature. Beet armyworm use their chewing mouth parts to eat through the flower. They drop and use sand and soil particles to make a pupal chamber and pupate. The life cycle can be completed in as few as 24 days, and they are present throughout the year in Florida (Capinera 1999). This species is an important pest of various crops (i.e., cabbage, broccoli, tomatoes) including vegetable crops, ornamentals, grasses, and weeds (Capinera 1999; Capinera 2008). Although this moth has not been found in large numbers on pitaya in south Florida, it has the potential of becoming a significant pest. There are parasitoids in the Braconidae (Hymenoptera) and Tachinidae (Diptera) families, predators such as the minute pirate bug, Orius spp. (Hemiptera: Geocoridae), and others that serve as natural enemies for this pest (Capinera 1999). 


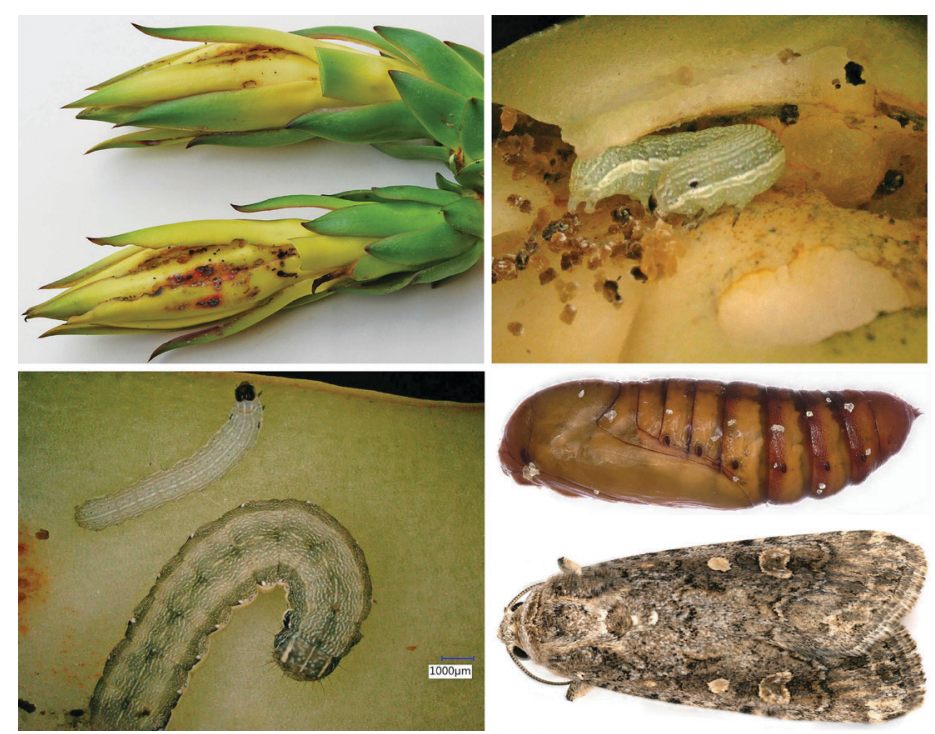

Figure 18. Spodoptera exigua (Hübner). Top left: damage from moth larvae to the flowers. Top right: close-up of the damage and larva. Center left: small and large larvae. Center right: pupa. Bottom: adult. Determined by J. Hayden, 4 June 2019.

Credits: Rita Duncan, UF/IFAS

\section{Scales on Fruit}

Philephedra tuberculosa Nakahara and Gill (Hemiptera: Coccidae) was found for the first time on pitaya in south Florida in June 2010 (Figure 19). These are soft scales; the mature females are $3-5 \mathrm{~mm}$ long and green to yellow. They produce an egg sac densely covered with white waxy filaments (Figures 19 and 20). The male larvae and pupae are visible through their transparent waxy covering that is sparsely covered with thin waxy filaments (Figures 21 and 22). Only the males develop wings and are capable of flight. Female fertility rate is very high; in a study on sugar apple (Annona squamosa) (Peña et al. 1984), each female produced up to 709 crawlers (immatures, nymphs) (Figure 20, yellow arrow). Life span is approximately 24 days for males and 59 for females (Peña et al. 1984). Since scales in general prefer hot and humid weather, in south Florida they are present all year. They feed on plant sap and produce honeydew. This secretion is conducive to the growth of sooty mold, which in turn blocks photosynthesis and makes the fruit less marketable. So far, this scale has not developed into a major problem on pitaya, but it is a key pest of papaya (Carica papaya L.) in this area and can also be a problem on sugar apple (Annona squamosa L.). There are many predators such as ladybugs (Figure 35), lacewings (Figure 36), and parasitoids, for example, Coccophagus lycimnia Walker (Hymenoptera: Aphelinidae), Trichomastus portoricensis Crawford, and Metaphycus sp. (Hymenoptera: Encyrtidae), that help to control scales in those crops (Peña et al. 1987 and unpublished data). Figure 23 is a $P$. tuberculosa scale detached from the leaf to expose the inside; it now contains four parasitoid larvae from the genus Metaphycus that have consumed the inner parts of the scale. These endoparasitoids pupate inside the scale, and the adults will leave emergence holes as they exit (Figure 24); a telltale sign that the scale was parasitized.

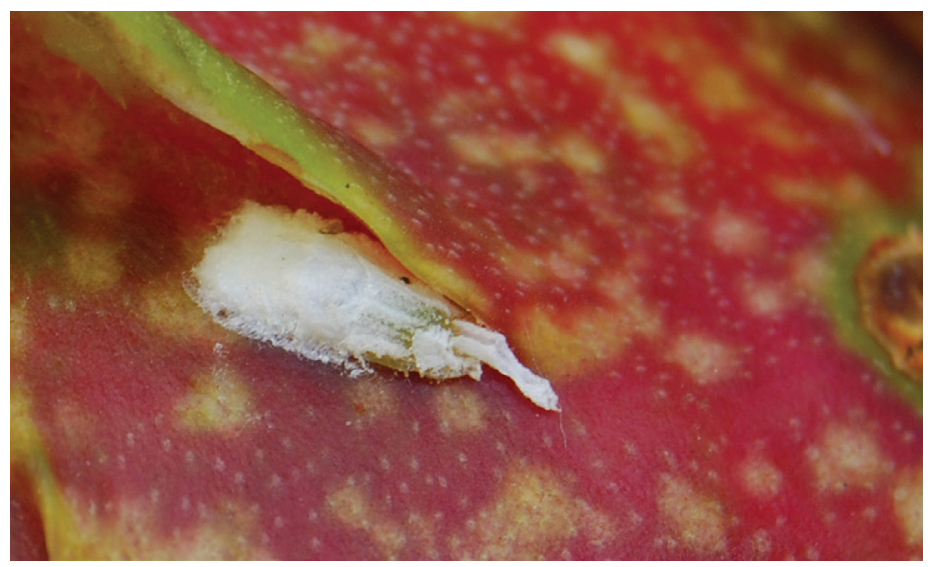

Figure 19. Philephedra tuberculosa Nakahara \& Gill scale on a pitaya fruit, female with ovisac. Determined by l. Stocks, 23 June 2010. Credits: Rita Duncan, UF/IFAS

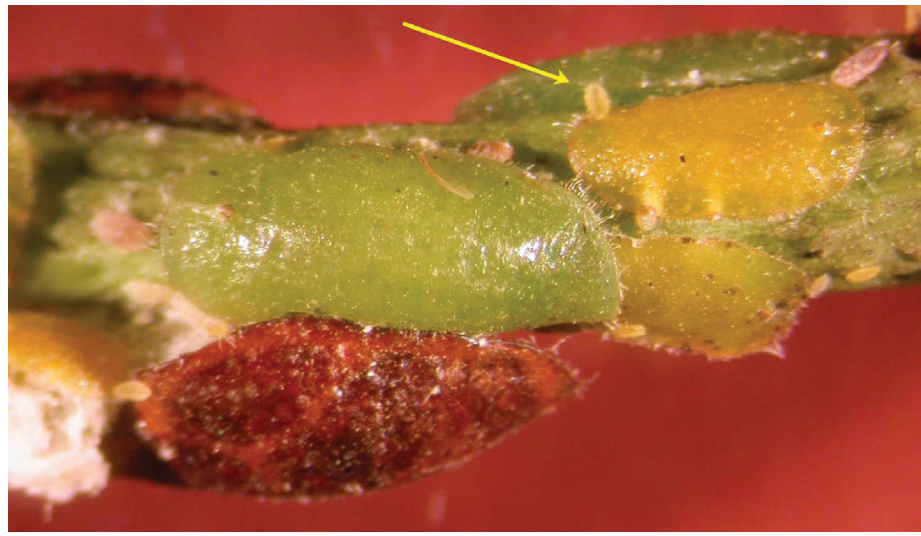

Figure 20. Philephedra tuberculosa Nakahara \& Gill scale on a papaya (Carica papaya) stem, females and crawlers or nymphs (yellow arrow). Determined by J. Peña, UF/IFAS.

Credits: Rita Duncan, UF/IFAS

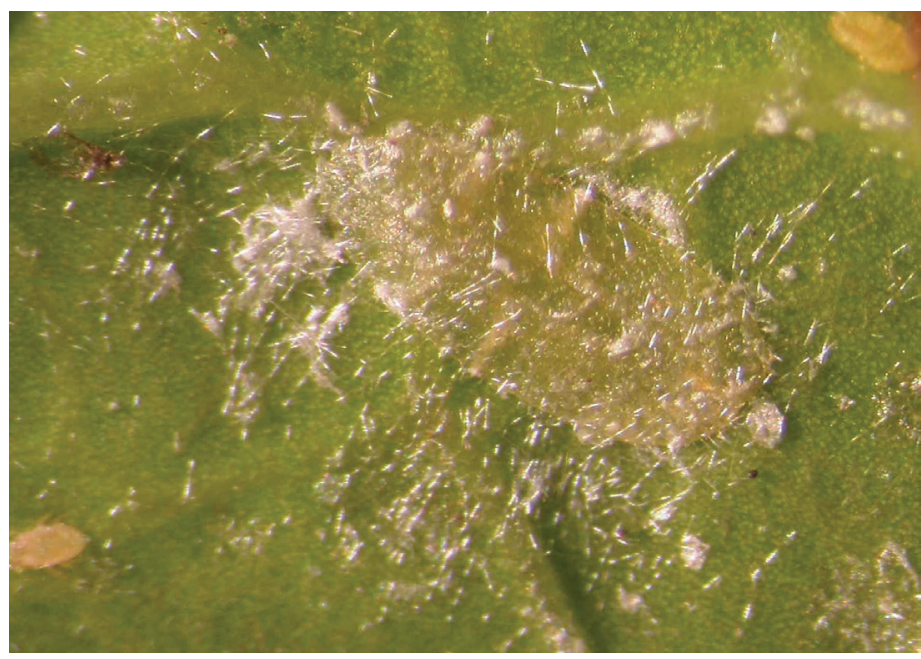

Figure 21. Philephedra tuberculosa male larva sparsely covered with wax filaments on a papaya leaf (Carica papaya). Determined by J. Peña, UF/IFAS.

Credits: Rita Duncan, UF/IFAS 


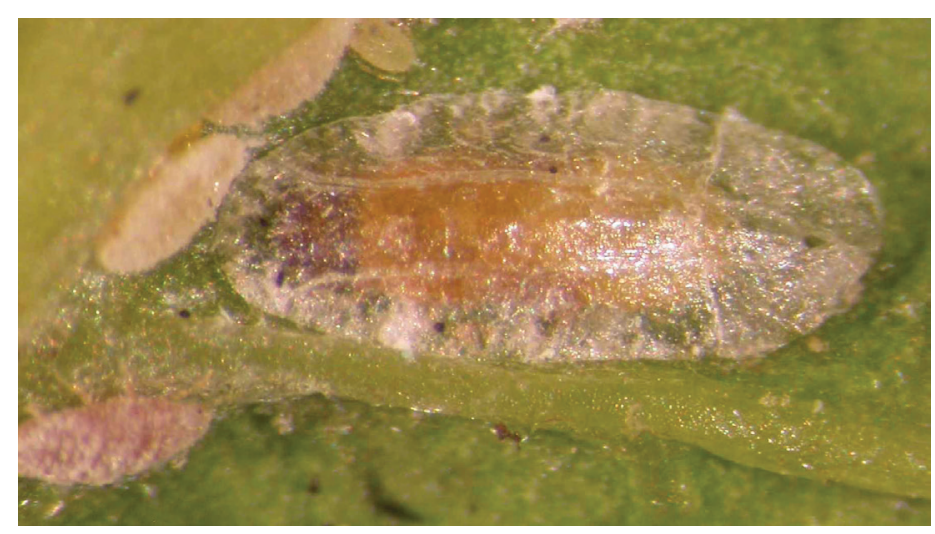

Figure 22. Philephedra tuberculosa male pupa on a papaya leaf (Carica papaya). Determined by J. Peña, UF/IFAS.

Credits: Rita Duncan, UF/IFAS

\section{BENEFICIAL WASP PARASITES}

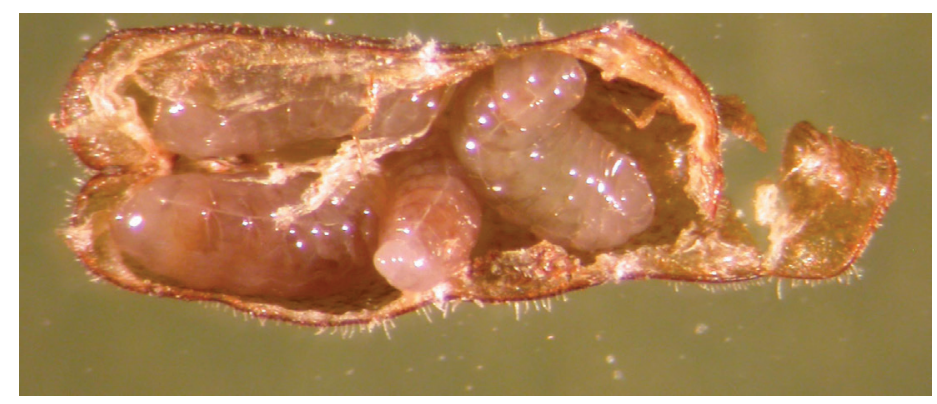

Figure 23. Parasitized Philephedra tuberculosa female opened to show the parasitoid larvae; from an infestation on papaya (Carica papaya). Determined by Rita Duncan, UF/IFAS.

Credits: Rita Duncan, UF/IFAS

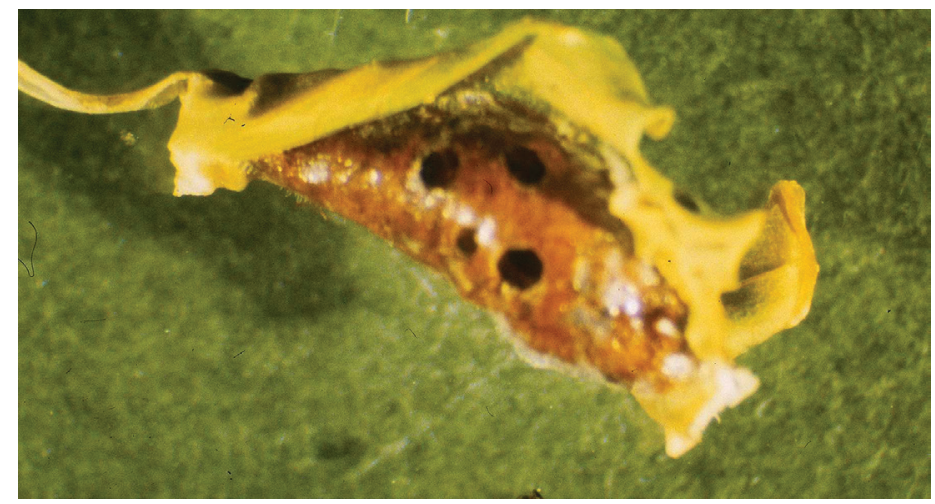

Figure 24. Holes in a female Philephedra tuberculosa carved by adult wasp parasitoids (Metaphycus sp.) as they emerged; from an infestation on papaya (Carica papaya). Determined by G. Evans. Credits: Rita Duncan, UF/IFAS

\section{Scales on the Stems}

The scale, Diaspis echinocacti (Bouche) (Hemiptera: Diaspididae) (Figure 25), has been found infesting the stems of pitaya plants. This is a hard scale (a waxy or resin covering over the scale), but like the soft scale Philephedra mentioned above, it also feeds on the sap of the plant and produces honeydew, resulting in similar damage. Scales are regularly controlled by natural enemies; however, when their natural enemies are disrupted, they become abundant enough to be considered a pest and require control (Figure
26). Sanitation, pruning and removal of the infested parts, and good cultural practices are recommended to keep scale populations at manageable levels (Crane et al. 2005). Zaomma lambinus (Walker) (Hymenoptera: Encyrtidae) (Figure 27) was reared from Diaspis echinocacti, cactus scale. This beneficial wasp may be a contributing factor in regulating the scale populations on pitaya.

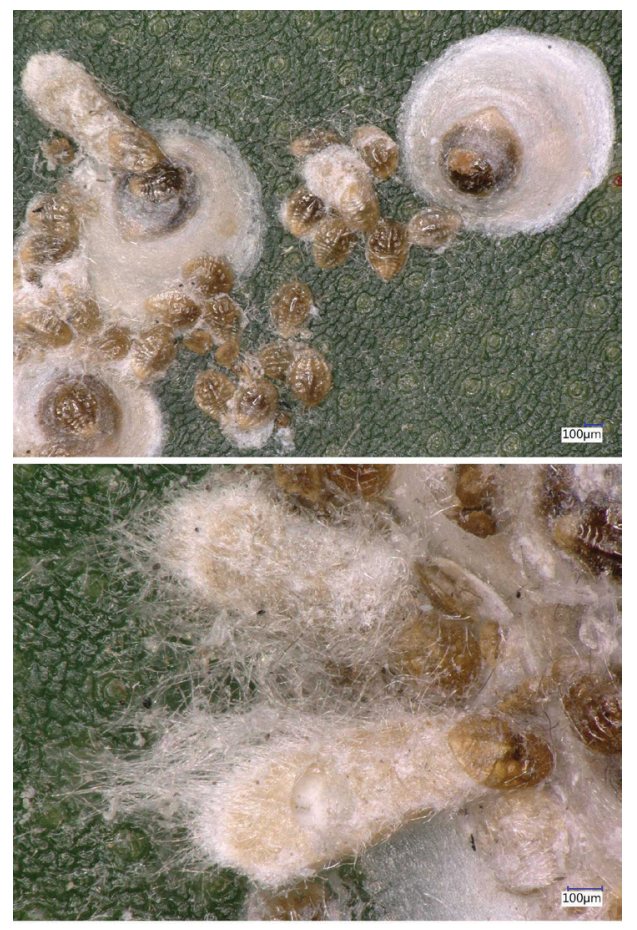

Figure 25. Diaspis echinocacti (Bouche) scale on pitaya. Top, a small colony with males and females. Bottom, a close up of the males with waxy filaments. Determined by I. Stocks, 16 Jul 2015.

Credits: Rita Duncan, UF/IFAS

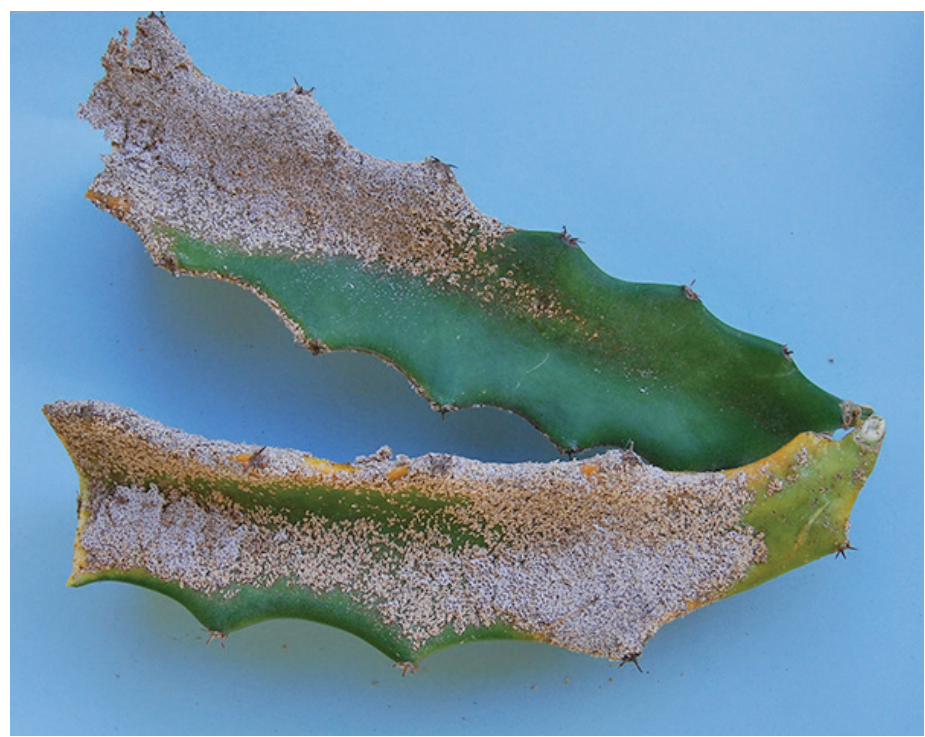

Figure 26. A large infestation of Diaspis echinocacti scales on the stems of pitaya cactus. Determined by I. Stocks, 17 Dec 2014.

Credits: Rita Duncan, UF/IFAS 


\section{BENEFICIAL WASP PARASITES}

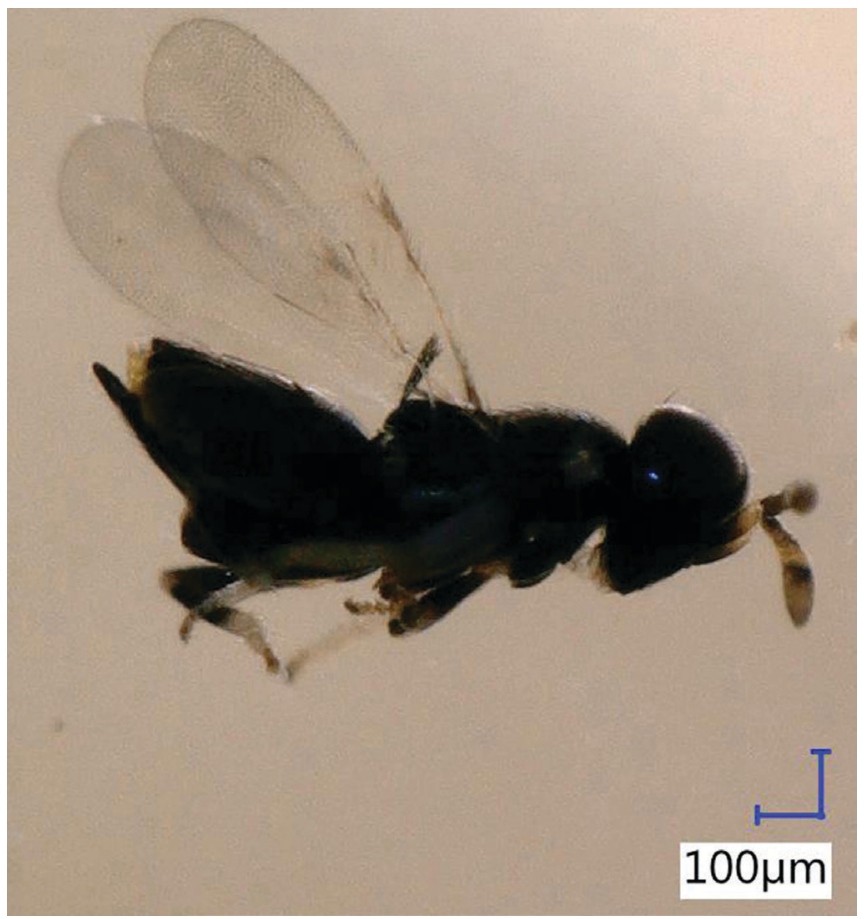

Figure 27. Zaomma lambinus (Walker) is a small beneficial wasp parasitizing cactus scale. Determined by K. Williams, 10 Dec 2014. Credits: Rita Duncan, UF/IFAS

\section{Beetles}

Banded cucumber beetles, Diabrotica balteata LeConte (Coleoptera: Chrysomelidae), (Figure 28) have been found feeding on pitaya flowers (Figure 29). Occasionally beetle populations increase and cause significant damage. Adults are 5 to $6 \mathrm{~mm}$ long and live 26 days on average. Females may produce 850 eggs in their lifetime (Capinera 1999). These beetles have a wide host range; Cucurbitaceae, Rosaceae, Leguminoseae, and Crucifereae are some of the preferred hosts (Saba 1970). The larvae feed only on the roots of plants while adults feed on flowers, fruits, and stems. These are tropical and subtropical insects found throughout the year in south Florida; the highest populations in a 13-year study in Mexico occurred from May to July, the hottest and most humid months in the area of study (Rodriguez and Magallanes 1994). Weed control is one of the tactics recommended to contain banded cucumber beetle populations because some of the species' many hosts are weed species (Capinera 1999).

The beetle Myctides imberbis Lea (Coleoptera: Curculionidae) (Figure 30) is normally found feeding in large numbers on wax jambu (Syzygium samarangense) fruits and has been found on pitaya plants grown adjacent to these groves. These are small weevils, between 4-6 $\mathrm{mm}$ in length. In south Florida they have also been found feeding on guava (Psidium guajava), Suriname cherry (Eugenia uniflora), and Brazil cherry (Eugenia brasilensis), and they have been spotted ovipositing in carambola (Averrhoa carambola) (unpublished data) (Figure 31). Originally from Australia where it is a pest of rose apple and other members of the Myrtaceae family, the beetle is now in Miami-Dade, Broward, Collier, and Martin Counties in Florida (FDACS 2019). Rose apple is the common name for several species of the genus Syzygium (including S. samarangense). This curculionid beetle has not achieved pest status.

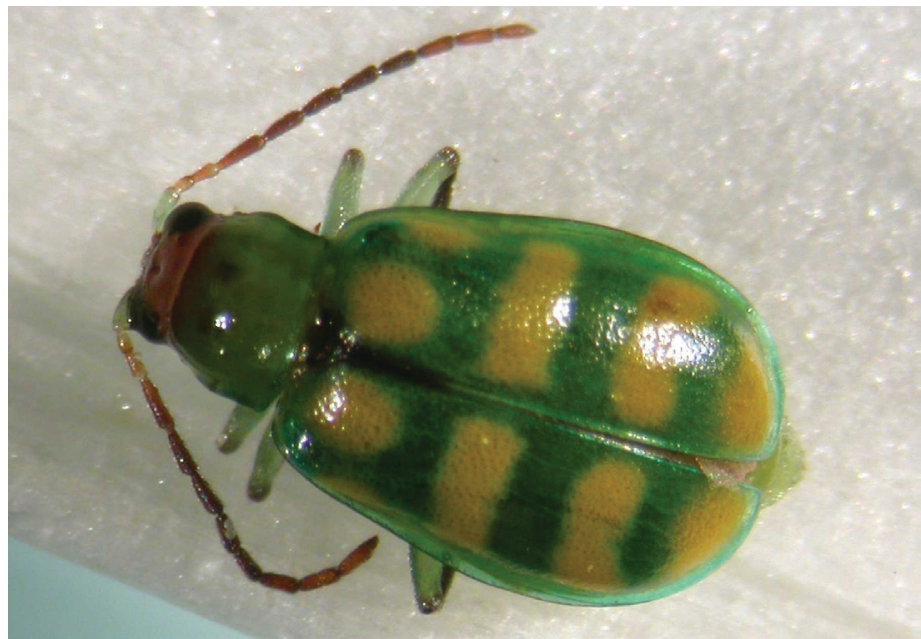

Figure 28. Banded cucumber beetle, Diabrotica balteata LeConte. Determined by M. Thomas, 9 June 2011.

Credits: Rita Duncan, UF/IFAS

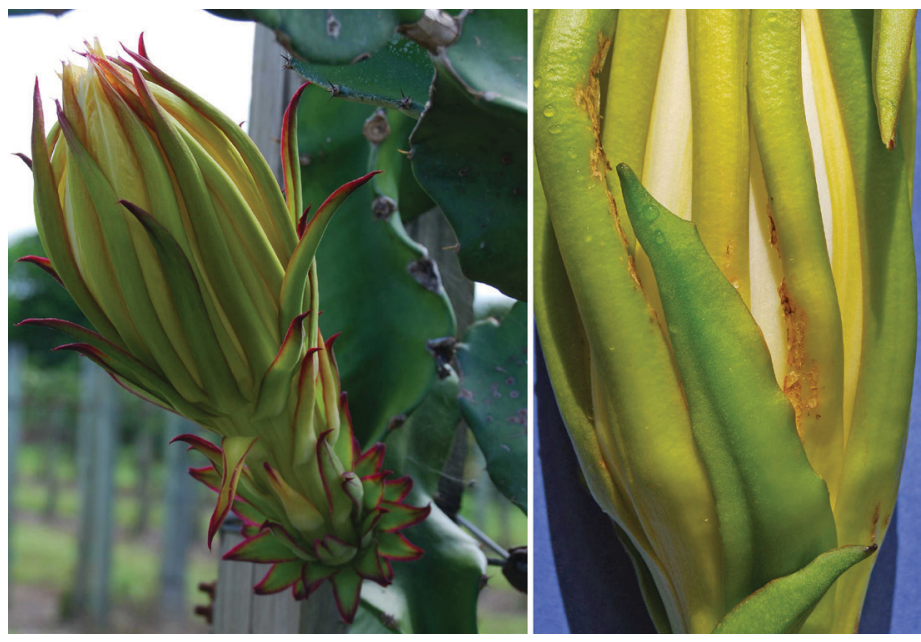

Figure 29. Pitaya flowers. Left, undamaged flower. Right, sepals with damage caused by banded cucumber beetles, Diabrotica balteata LeConte.

Credits: Rita Duncan, UF/IFAS

The dark flower scarab, Euphoria sepulcralis (Fabricius) (Coleoptera: Scarabaeidae), has been observed in pitaya flowers occasionally, but it has not reached pest status. Adults are 10 to $12 \mathrm{~mm}$ long (Figure 32) and found on the flowers of a wide range of plants. This scarab beetle has been reported as a pest of corn and roses; it pupates in the soil but not much is known about the immature stages (Thomas 2007). In Alachua County, dark flower scarab 
populations peak in August, but they have been collected throughout the year in Florida except for October and December (Thomas 2007).

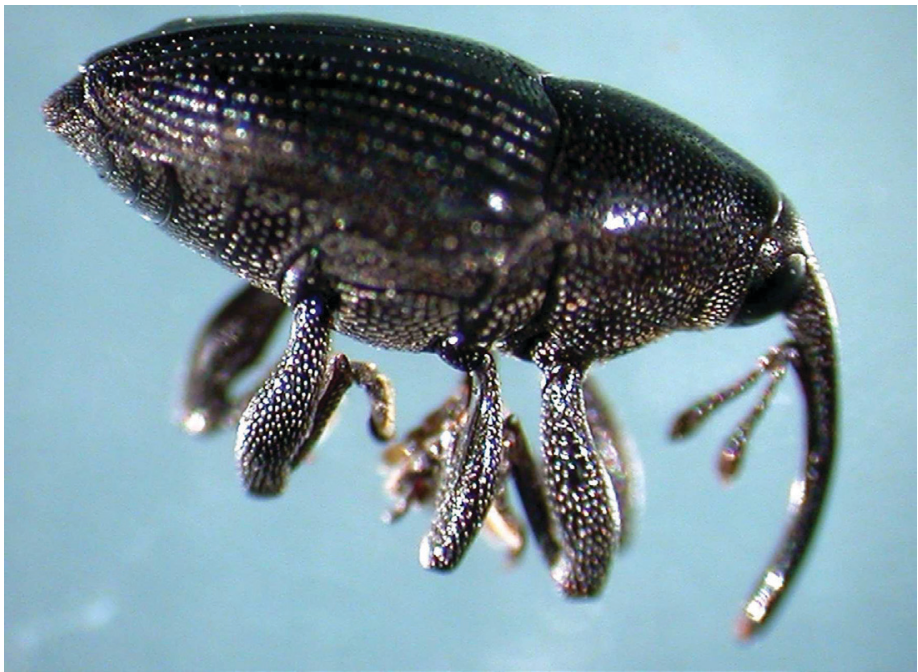

Figure 30. An adult Myctides imberbis Lea, a beetle occasionally found on pitaya. Determined by P. Skelley, 27 Aug 2013.

Credits: Rita Duncan, UF/IFAS

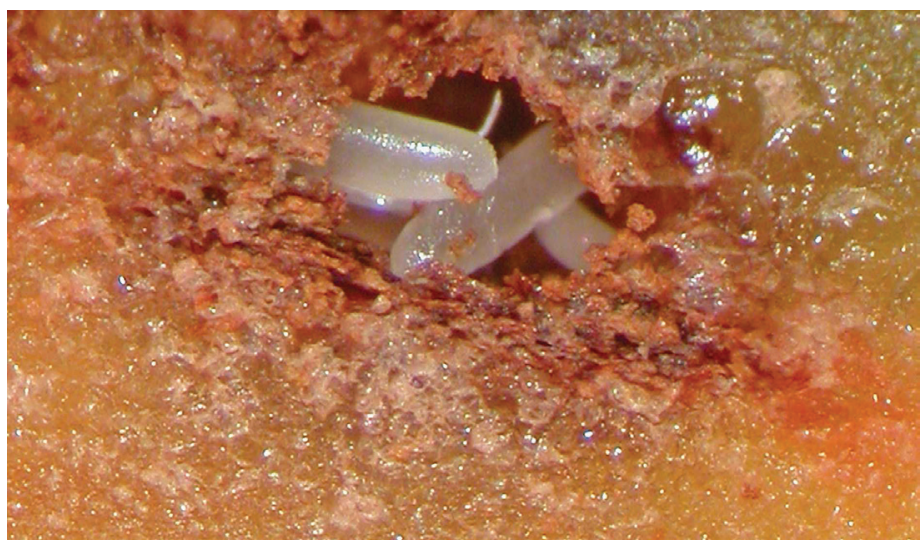

Figure 31. Myctides imberbis Lea eggs oviposited in carambola fruit. Credits: Rita Duncan, UF/IFAS

There is a complex of sap beetles from the family Nitidulidae (Coleoptera) that may be pollinating pitaya flowers. Nitops craigheadi (Dobson) is one of the most prominent of these beetles found in freshly opened flowers (Figure 33). Nitops craigheadi was previously named Carpophilus craigheadi and was transferred to this genus in 2007 (Kirejtshuk et al. 2007). Five species in this genus were detected entering Annona flowers in the early mornings (7-9 AM) and evenings (5-9 PM) in a pollination study in south Florida (Nadel and Peña 1994). Sap beetle adults and larvae are regularly found in rotting fruit; however, adults are the main pollinators of Annona in south Florida, Israel, and Australia (Nagel and Peña 1989; Nadel 1990). They are considered a pest in Mexico, and the larvae have been observed feeding on damaged fruits in south Florida. Large numbers of adults and larvae are conspicuously visible in the flowers in this region; however, there is little or no damage observed (Figure 34). Their primary role as pollinators or secondary pests that may transmit pathogens is unclear and requires further research. Bats and hack moths have been reported as pollinators (Gunasena et al. 2006); however, they have not been observed pollinating in south Florida (Crane et al. 2005). In Sri Lanka, bees have been observed in the early morning pollinating flowers that were not already pollinated at night (Gunasena et al. 2006).

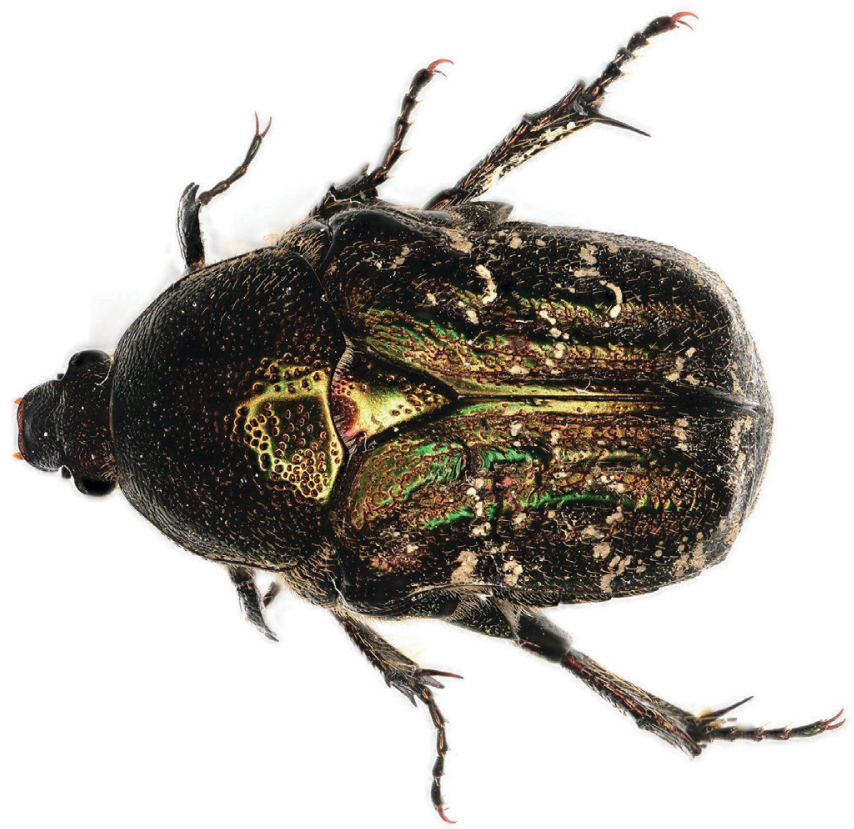

Figure 32. The dark flower scarab beetle, Euphoria sepulcralis (Fabricius). Identified by K. Schnepp, 30 May 2019.

Credits: Rita Duncan, UF/IFAS
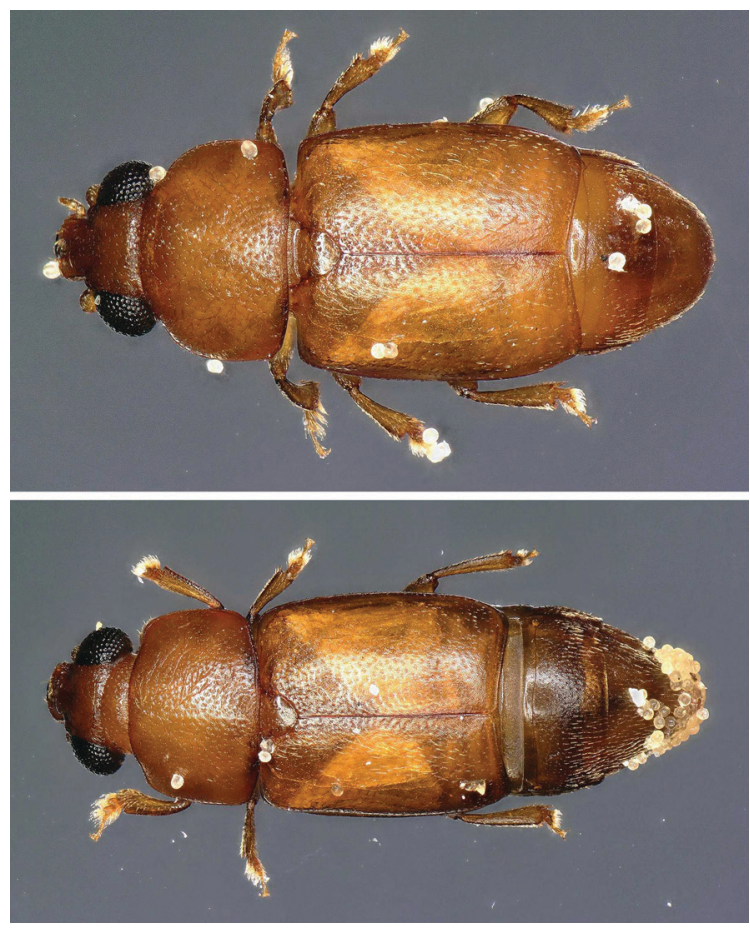

Figure 33. Nitops craigheadi (Dobson). Male (top) and female (bottom) beetles carrying pollen grains. Determined by Kyle Schnepp, 17 May 2019.

Credits: Rita Duncan, UF/IFAS 

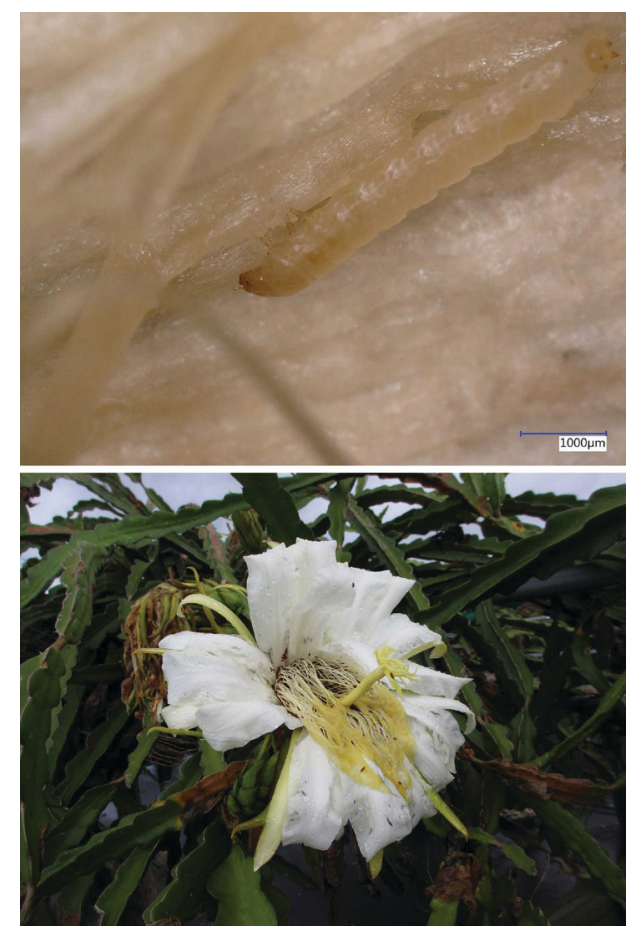

Figure 34. Nitidulid beetles. Top, larva on the petals and stamen of a pitaya flower. Bottom, flower with a large number of adults. Credits: Rita Duncan (top) and Daniel Carrillo (bottom), UF/IFAS

\section{Generalist Beneficial Fauna}

There are some common predators that feed on a variety of pests such as ladybugs (ladybird beetles) (Coleoptera: Coccinellidae) (Figure 35) and lacewing larvae (Neuroptera: Chrysopidae) (Figure 36). These predators keep insects from becoming pests by reducing their population size. Good cultural control methods and minimizing insecticides will help to preserve these natural enemies.

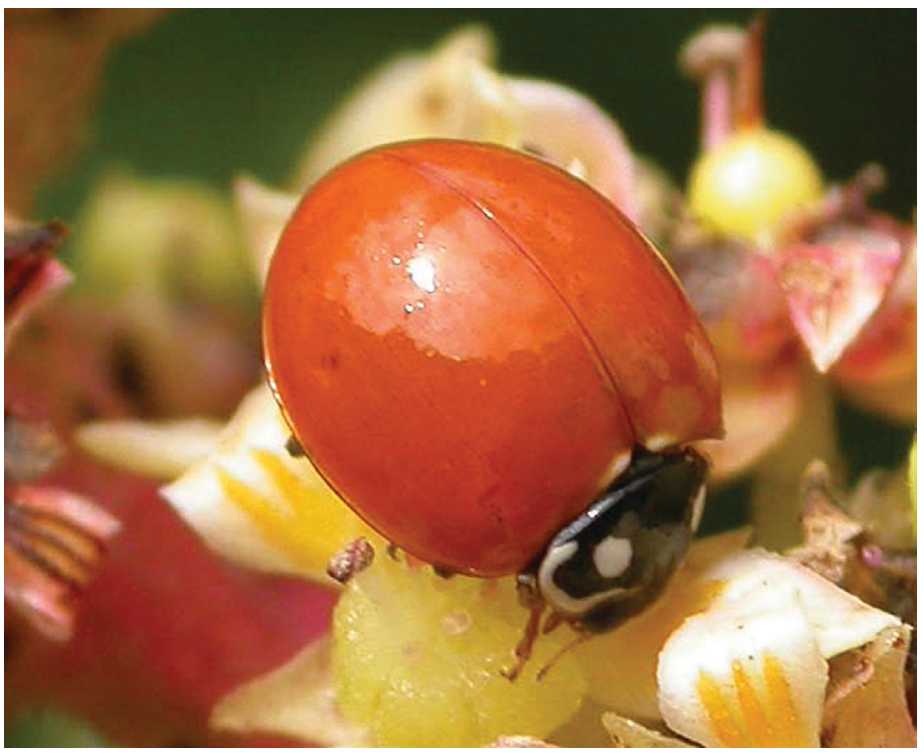

Figure 35. Ladybugs (ladybird beetles) are common generalist predators.

Credits: Rita Duncan, UF/IFAS
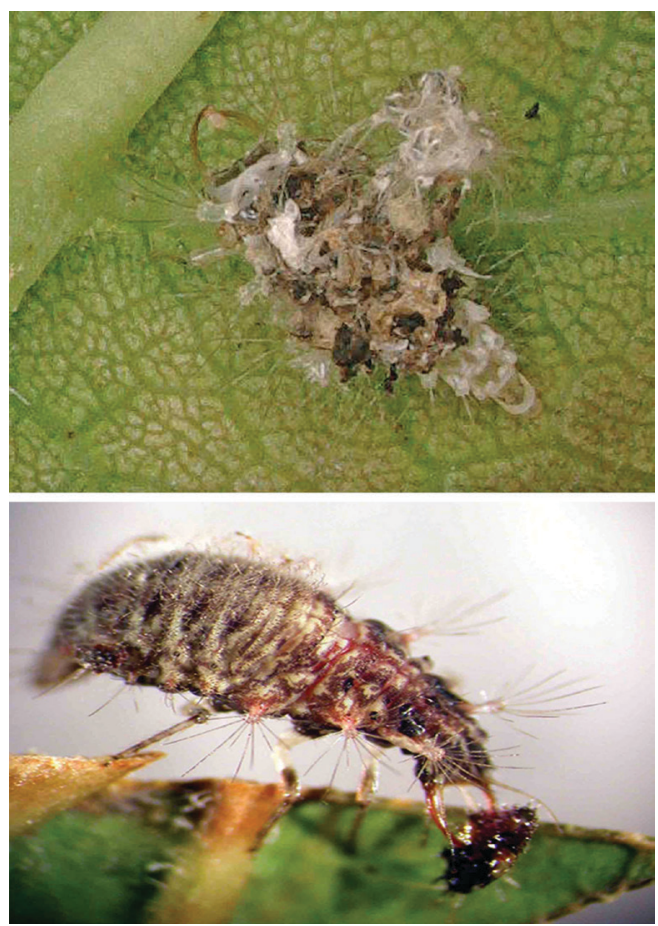

Figure 36. Lacewing larvae are a common generalist predator referred to as trash bugs (they have a habit of covering themselves with debris). Top, a larva with "trash" cover. Bottom, larva with debris removed feeding on avocado lace bug.

Credits: David Long, UF/IFAS

\section{Visitors}

Picture wing flies, Euxesta abdominalis Loew (Diptera: Udidiidae) have been found visiting pitaya flowers (Figure 37). This fly is common, widespread, and not a plant pest (G. Steck, personal communication).

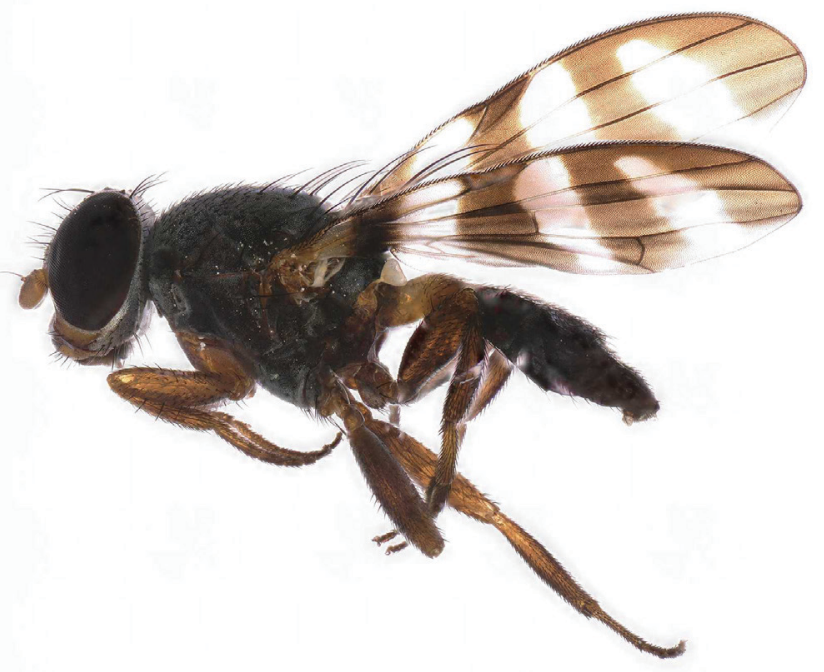

Figure 37. Euxesta abdominalis Loew, a picture wing fly found visiting pitaya flowers. Identified by G. Steck, 31 May 2019. Credits: Rita Duncan, UF/IFAS 


\section{Potential Pests}

We should be on the lookout for some key insect species that have the potential to become a problem for pitaya in south Florida.

Leptoglossus zonatus (Dallas) is a leaf-footed bug causing damage to pitaya in Nicaragua (OIRSA 2000), Colombia (Medina and Kondo 2012), and Mexico (Cruz et al. 2015). It is a minor pest of fruits and vegetables in the United States along the Gulf Coast, but it has caused considerable damage to satsuma mandarin in Louisiana and Alabama (Chi and Mizell 2012; Halbert, pers. comm.). To date, it has not been collected in the pitaya-growing region in MiamiDade County (Halbert 2019; FDACS DPI database, pers. comm.). The adult is similar to L. concolor (Figure 6) and $L$. phyllopus (Figure 7), but it has two distinct yellow spots on the pronotum (yellow arrow) (Figure 38).

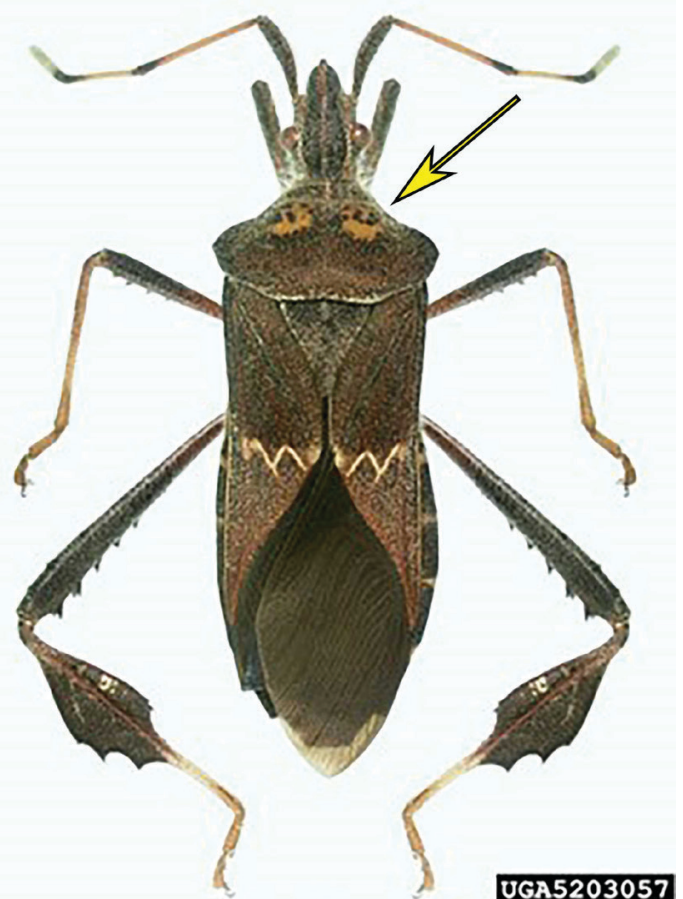

Figure 38. Adult western leaf-footed bug, Leptoglossus zonatus (Dallas). Credits: Natasha Wright, Florida Department of Agriculture and Consumer Services

The cactus moth, Cactoblastis cactorum (Berg), is an invasive pest first found in the Florida Keys in 1989 and now seen throughout the state. This moth is a major pest of Opuntia cacti and could become a problem for pitaya growers (Figure 39). For more information on this species, please see the Featured Creatures article (Habeck et al. 1998) on this pest: http://entnemdept.ufl.edu/creatures/ bfly/cactus_moth.htm.

The fly, Dasiops saltans Townsend (Diptera: Lonchaeidae), is a potential invasive pitaya flower pest to Florida and a major pest of yellow pitaya in Colombia. The adult females oviposit their eggs in the flowers, and the larval feeding destroys the blooms (Figure 40) (Delgado et al. 2010). Three baits were successfully tested in Colombia to capture this fly, but many similar species difficult to differentiate from D. saltans were also captured with the same baits; therefore, the authors do not recommend using baits for monitoring this pest (Imbachi 2013).
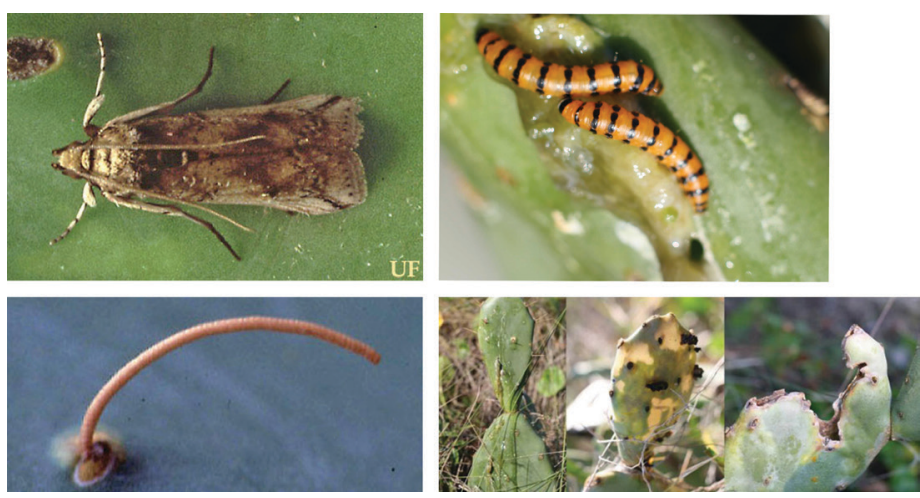

Figure 39. Cactoblastis cactorum (Berg), the cactus moth. Adult (top left), larvae (top right), egg stick (bottom left), and damage (bottom right).

Credits: D. Habeck (top left), F. Bennett (bottom left), and C. Miller (top and bottom right), University of Florida

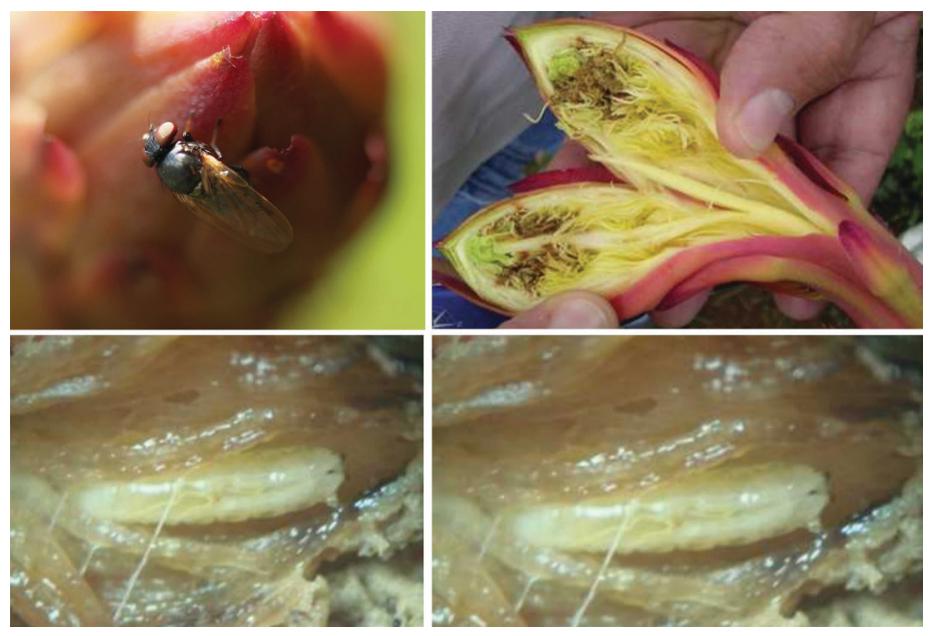

Figure 40. Dasiops saltans, a fly causing damage to pitaya in Colombia. An adult on a flower (top left). A flower with larval feeding damage (top right). A close up of a larva (bottom left). The exit hole caused by the emerging adult (bottom right).

Credits: T. Kondo; larva by A. Delgado, CORPOICA

Pitaya is included in the USDA list of host species for the oriental fruit fly, Bactrocera dorsalis (Hendel) (Diptera: Tephritidae). This is a serious pest that, from time to time, has necessitated the quarantining of portions of south Florida to eradicate the pest. Currently, it is not established in south Florida. For more information on this species, please see the Featured Creatures article (Weems and Heppner 2019) on this pest: http://entnemdept.ufl.edu/ creatures/fruit/tropical/oriental_fruit_fly.htm. 


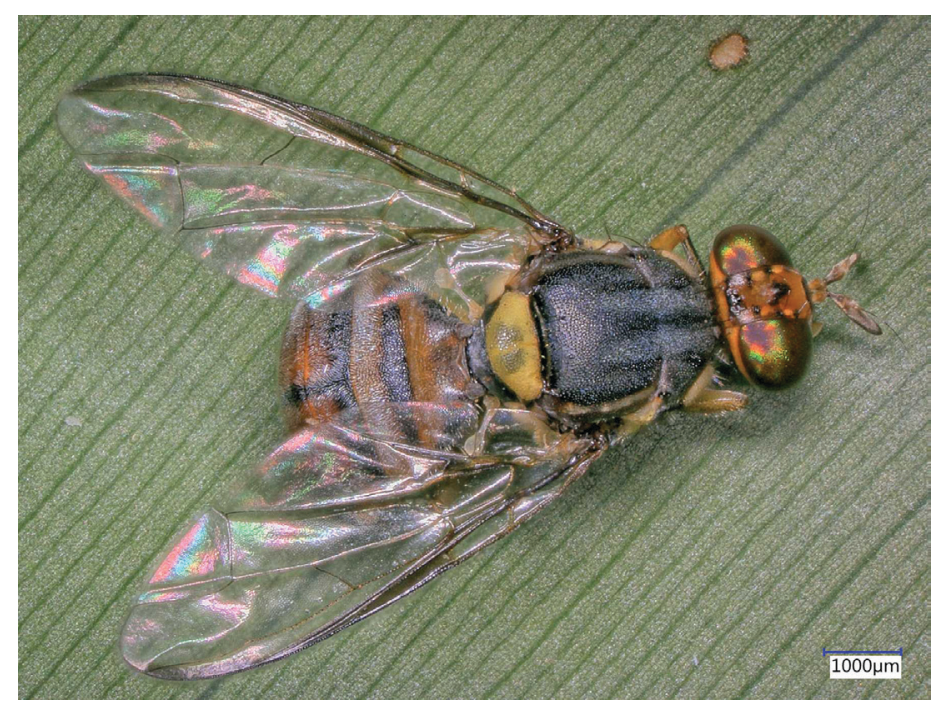

Figure 41. Oriental fly adult. Determined by Daniel Carrillo, UF/IFAS. Credits: Daniel Carrillo, UF/IFAS

\section{Control, Precautions, and Restrictions}

Pitaya plants are subject to attack by several insects; however, only a few insect species populations have increased to levels high enough for the species to be considered pests. Key pests may require immediate attention and control. Minor pests should be monitored but will normally remain under biological control by beneficial insects and good cultural practices. Biological and cultural management tactics should be the primary method for controlling insects that have a tendency to become pests. For a list of pesticides, fungicides, lures, and oils registered for pitaya, please go to the CDMS website at http://www.cdms.net/Label-Database/ Advanced-Search. Please be advised that efficacy data is not available for some of these products; also, the user must read pesticide and fungicide labels carefully and adhere to regulations. The local county agricultural Extension office may be able to provide more information on pest control materials.

\section{References}

Capinera, J. L. 1999. Diabrotica balteata LeConte (Insecta: Coleoptera: Chrysomelidae). EENY-93. Gainesville: University of Florida Institute of Food and Agricultural Sciences. https://edis.ifas.ufl.edu/in250

Capinera, J. L. 1999. Spodoptera exigua (Hübner) (Insecta: Lepidoptera: Noctuidae). EENY-105. Gainesville: University of Florida Institute of Food and Agricultural Sciences. https://edis.ifas.ufl.edu/in262

Capinera, J. L. 2008. Encyclopedia of Entomology $2^{\text {nd }}$ Edition. Springer. $4346 \mathrm{pp}$.
Capinera, J. L. 2015. Frankliniella bispinosa Morgan (Insecta: Thysanoptera: Thripidae). EENY-639. Gainesville: University of Florida Institute of Food and Agricultural Sciences. https://edis.ifas.ufl.edu/in1110

Chi, A. A., and R. F. Mizell III. 2012. Leptoglossus zonatus (Dallas) (Insecta: Hemiptera: Coreidae). EENY-517. Gainesville: University of Florida Institute of Food and Agricultural Sciences. https://edis.ifas.ufl.edu/in935

Childers, C., and S. Nakahara. 2006. "Thysanoptera (Thrips) within citrus orchards in Florida: species distribution, relative and seasonal abundance within trees, and species on vines and ground cover plants." Journal of Insect Science 6 (45): 1-19.

Crane, J. H., and C. F. Balerdi. 2005. Pitaya Growing in the Florida Home Landscape. HS1068. Gainesville: University of Florida Institute of Food and Agricultural Sciences. https:// edis.ifas.ufl.edu/hs303

Cruz, J. A. M., C. L. Rodriguez-Larramendi, C. R. OrtizPerez, M. A. Fonseca-Flores, G. R. Herrera, and C. F. Guevara-Hernadez. 2015. "Cultivos Tropicales." La Habana. $36(1)$.

Delgado, A., T. Kondo, K. I. López, E. M. Quintero, M. B. Burbano, and J. A. Medina. 2010. "Biología y algunos datos morfológicos de la mosca del botón floral de la pitaya amarilla, Dasiops saltans (Townsend) (Diptera: Lonchaeidae) en el Valle del Cauca, Colombia." Boletín del Museo de Entomología de la Universidad del Valle. 11 (2): 1-10.

FDACS. 2019. "Coleoptera, Florida Beetle Collection. "https://www.fdacs.gov/Divisions-Offices/Plant-Industry/ Florida-State-Collection-of-Arthropods/Explore-theCollection/Insect-Collection/Coleoptera/Florida-BeetleChecklist/Suborder-Polyphaga/Series-Cucujiformia/ Curculionoidea/Curculionidae

Gunasena, H. P. M., D. K. N. G. Pushpakumara, and M. Kariyawasam. 2006. Dragon Fruit - Hylocereus undatus (Haw.) Britton and Rose: Field Manual for Extension Workers. Sri Lanka: Sri Lanka Council for Agricultural Policy. http://www.worldagroforestry.org/downloads/Publications/ PDFS/BC07324.pdf

Habeck, D. H., F. D. Bennett, and C. Miller. 1998. Cactoblastis cactorum (Berg) (Insecta: Lepidoptera: Pyralidae). EENY-56. Gainesville: University of Florida Institute of Food and Agricultural Sciences. https://edis.ifas.ufl.edu/ in 213 
Imbachi, K., E. Quintero, M. Manrique, and T. Kondo. 2013. "Evaluation of three hydrolyzed proteins for capturing adults of the yellow pitaya flower-bud fly, Dasiops saltans Townsend (Diptera: Lonchaeidae) [2012]." Corporación Colombiana de Investigación Agropecuaria 13 (2): 159-166.

Kirejtshuk, A. G., A. S. Kurochkin, and R. F. Monteiro. 2007. "Imagines and larvae of the new species of the genus Nitops Murray, 1864 (Coleoptera: Nitidulidae: Carpophilinae) from Brazil and notes on their bionomy." Russian Entomol. J. 16 (3): 301-315.

Marques, C. E. M., M. S. Lima, and J. W. S. Melo. 2015. "Evaluation of Ferrisia dasylirii (Cockerell) (Hemiptera: Pseudococcidae) and non-prey foods on the development, reproduction and survival of Cryptolaemus montrouzieri Mulsant (Coleoptera: Coccinellidae)." The Coleopterists Bulletin 69 (2): 343-348.

Medina, J. A., and T. Kondo. 2012. "Listado taxonómico de organismos que afectan la pitaya amarilla, Selenicereus megalanthus (K. Schum. ex Vaupel) Moran (Cactaceae) en Colombia." Revista Corpoica - Ciencia y Tecnología Agropecuaria 13 (1): 41-46.

McCorquodale, A., and A. Hodges. 2016. Ferrisia virgata Cockerell (Insecta: Hemiptera: Pseudococcidae). EENY-674. Gainesville: University of Florida Institute of Food and Agricultural Sciences. https://edis.ifas.ufl.edu/in1164

Nadel, H. 1990. "Beetle pollination of sugar apples \& atemoyas.” Tropical Fruit News May: 4-5.

Nadel, H., and J. E. Peña. 1994. Identity, behavior, and efficacy of Nitidulid beetles (Coleoptera: Nitidulidae) pollinating commercial Annona species in Florida. Population Ecology 23 (4): 878-886.

Nagel, J., and J. E. Peña. 1989. Insect pollination of atemoya in Florida. Florida Entomologist 72 (1): 207-211.

OIRSA. 2000. Manual técnico buenas practicas de cultivo en pitahaya. Organismo Internacional Regional de Sanidad Agropecuaria. Nicaragua.

Peña, J. E., H. Glenn, and R. M. Baranowski. 1984. "Important pests of Annona spp. in Florida." Proc. Fla. State Hort. Soc. 97:337-340.
Peña, J. E., R. M. Baranowski, and R. E. Litz. 1987. "Life history, behavior and natural enemies of Philephedra tuberculosa (Homoptera: Coccidae)." Florida Entomologist 70 (4): 423-427.

Peña, J. E., J. L. Sharp, and M. Wysoki. 2002. Tropical Fruit Pests and Pollinators: Biology, Economic Importance, Natural Enemies and Control. CABI Publishing. 430 pp.

Rodriguez-del-Bosque, L. A., and A. Magallanes-Estala. 1994. "Seasonal abundance of Diabrotica balteata and other Diabroticina beetles (Coleoptera: Chrysomelidae) in northeastern Mexico." Environmental Entomology 23 (6): 1409-1415.

Saba, F. 1970. "Host plant spectrum and temperature limitations of Diabrotica balteata." Canadian Entomologist 102: 684-691.

Thomas, M. C. 2007. A Flower Beetle, Euphoria sepulcralis (Fabricius) (Insecta: Coleoptera: Scarabaeidae). EENY-416. Gainesville: University of Florida Institute of Food and Agricultural Sciences. http://edis.ifas.ufl.edu/in750

Weems, H. V., and J. B. Heppner. 1999. Bactrocera dorsalis (Hendel) (Insecta: Diptera: Tephritidae). EENY-83. Gainesville: University of Florida Institute of Food and Agricultural Sciences. https://edis.ifas.ufl.edu/in240

Xiao, Y. 2009. Biology, Ecology and Management of Key Pests of satsuma Citrus in Alabama. Ph.D. Dissertation. Auburn, AL: Auburn University. 177 pp. 